\title{
Reducing Women to Bare Life: Sexual Violence in South Africa
}

\author{
Amanda Gouws 1*
}

Published: March 5, 2021

\begin{abstract}
This article investigates rape through the lens of biopolitics, using Agamben's notion of a state of exception and bare life. I will argue that there needs to be a closer look at the neglected sexual and gender dimensions of biopolitics in settler colonial societies, and specifically at the continuities of sexual violence of the settler colony with high levels sexual violence in present day South Africa. Women in post-colonial South Africa are included in a state of exception giving rise to bare life through the abandonment by the law and state agencies that have to implement the law. I end by considering the possibilities of resistance against bare life ${ }^{1}$.
\end{abstract}

Keywords: South Africa, sexual violence, biopolitics, Agamben, bare life

\section{INTRODUCTION}

In July 2002 nine-month-old baby Tsepang was raped by her mother's boyfriend in a township in the Northern Cape $^{2}$. She survived. In February 2013 the 17-year-old Anene Booysen was found gang raped, disembowelled with her stomach slit open on a construction site in rural Bredasdorp ${ }^{3}$. She died in hospital. On Valentine's Day 2013 29-year-old Reeva Steenkamp, a model, was shot through a bathroom door and killed by her boyfriend, feted Paralympic athlete, Oscar Pistorius in Pretoria4. In July 2013 26-year-old Duduzile Zozo, a lesbian woman, was found half naked and dead with a toilet brush rammed into her vagina in Thokoza, near Johannesburg ${ }^{5}$. In December 2019 Uyinene Mrwetyana, a 19-year-old student went to pick up a parcel at a post office in Cape Town close to closing time. Inside she was raped and killed by a post office worker, her body moved and burned in an area outside Cape Town ${ }^{6}$. On 30 March 2020, 75-year-old Genzeni Zuma was raped and killed near Pietermaritzburg by men posing as soldiers doing sanitising under lock down for the COVID-19 pandemic 7 .

What these six rapes and/or femicides ${ }^{8}$ demonstrate are their widespread occurrence and normalisation in South Africa over time. These rapes occurred in different localities in the country, both urban and rural. The

${ }^{1}$ The author wants to thank Louise du Toit, Azille Coetzee and anonymous reviewers for helpful suggestions on earlier drafts of the article. This article is published in the Special Issue on the Anthropocene. Theorising (sexual) violence in the Anthropocene makes an important link with the continuation of practices of dispossession and genocide of colonisation. See for example Davis and Todd (2017).

2 For more information see "Baby Rape Sparks Outrage" [https://abcnews.go.com/WNT/story?id=130199\&page=1] (Accessed 13 November 2020)

${ }^{3}$ For more information see 'South African Anene Booysen Rapist Jailed for Life' [https://www.bbc.com/news/world-africa24768817] (Accessed 13 November 2020)

4 'Oscar Pistorius Jail Term for Killing Reeva Steenkamp More than Doubled' [https://www.bbc.com/news/world-africa42107701] (Accessed 13 November 2020)

${ }^{5}$ For more information see 'South Africa: Duduzile Zozo Murdered in Anti-Gay Hate Crime' [https://www.pri.org/stories/ 2013-07-02/south-africa-duduzile-zozo-murdered-anti-gay-hate-crime] (Accessed 13 November 2020)

${ }^{6}$ For more information see 'The Death of Uyinene Mrwetyana and the Rise of South Africa's “Am I Next”? Movement' [https://www.newyorker.com/news/news-desk/the-death-of-uyinene-mrwetyana-and-the-rise-of-south-africas-aminextmovement] (Accessed 13 November 2020)

${ }^{7}$ For more information see 'Granny, 75, allegedly Rape and Murdered by Men Posing as Soldiers' - MEC [https://www.news24.com/news24/SouthAfrica/News/granny-75-raped-and-murdered-allegedly-by-men-posing-as-

soldiers-mec-20200330] (Accessed 13 November 2020)

${ }^{8}$ See for example, Nechama Brodie's Femicide in South Africa (Cape Town: Kwela (2020)), documenting femicide. 
victims were of different ages, different classes and of different race groups. All the rapes were brutal resulting in death and/or the maiming of the bodies?.

No category of women in South Africa is excluded from being potential victims, but some women are more vulnerable than others, depending on the intersectionalities of race, class and sexuality. Geography plays an important role in the construction of vulnerability of women. Densely populated semi-permanent structures in African townships are less safe than middle-class neighbourhoods where most white women, for example, reside. It is, however, the case that most rapes and femicides are perpetrated by people known to the victims (StatsSA Report, 2000).

There is a relationship between the normalisation of sexual violence and the inaction of the state to deal with it. As a consequence of this normalisation often only the most gruesome incidents of sexual violence get reported in the media, usually involving the maiming of the body or resulting in intimate femicide. Other incidents only become statistics. The South African Police Services (SAPS) rape statistics for reported rapes for 2019/2020 is 42,289 and for sexual assault 7,749 (Department of Police, 2020). South Africa can therefore be considered a rapeprone society. A rape prone society has been defined as:

(a) society (...) in which the incidence of rape is reported by observers to be high, or rape is excused as a ceremonial expression of masculinity, or it is an act by which men are allowed to punish or threaten women (Sanday, 1996: 192).

All three of these factors apply to South Africa. Rape in rape-prone societies is not abnormal or anomalous, since it is part of the everyday systemic subversion of women's sexual subjectivity that is a devastating injury to women's psyche (Du Toit, 2009: 66).

Comparisons of the Victims of Crime Survey Report for 1997 with police data showed that on average 73 rapes occurred per 100000 women 18 years or older. Among all the cases reported to court $(47.6 \%)$ only one fifth $(19.8 \%)$ resulted in a conviction, while $45.6 \%$ were withdrawn before the cases were completed and $32 \%$ accounted for unsolved cases. While these statistics are old conditions have continued to deteriorate rather than improve, for example in 1998 convictions dropped to 8.9\%. (StatsSA, 2000: 2, 23) ${ }^{10}$. The same report shows that South Africa in $1996 \mathrm{had}$ the highest number of reported rape cases of selected countries. These 20 countries include countries not at war, but with have high levels of conflict, inter alia the USA, Argentina, Venezuela, Chile, Colombia and Uganda. A more recent report on crime against women also shows that 250 out of 100000 women were victims of sexual violence, of which $80 \%$ reported offences were rape, one of the highest statistics in the world (StatsSA, 2018).

While the rape statistics are staggering, the statistics for intimate femicide are equally stark. According to the World Health Organization the femicide rate in South Africa is 12.1 out of 100000 women. This is five times higher than the global average of 2.6 (Head, 2019). A study measuring a propensity for sexual violence with a sample of 1,368 men of all population groups shows that over $43.3 \%$ reported that they sexually assaulted women partners in the previous ten years with regular frequency (Abrahams, Jewkes, Laubsher and Hoffman, 2006).

Contracting HIV/Aids through sexual intercourse (and specifically rape) compounds sexual violence in South Africa with women being more vulnerable to contracting the disease. An April 2020 Avert Report showed that in South Africa in 2018, 140,000 women and 86,000 men became HIV positive. In the same year, 4.7 million women were living with HIV compared to 2.8 million men. The prevalence of HIV is four times greater among young women than young men (Avert Report, 2020).

Sexual violence is aggravated by the complicity of members of the South African Police Services in rape. A Report of the Independent Police Investigative Directorate (IPID) (2013) indicates that at that point there were 150 cases pending against members of the police for sexual assault and rape. Many women are raped in police custody. On 19 October 2019 the police Ombud ${ }^{11}$ also warned members of the police service not to turn victims of sexual violence away from police stations. It happens regularly that members of the police service refuse to take statements from rape victims, especially if they seem intoxicated or not 'well dressed' (read the rape myth - 'she was asking for it') (Cloete, 2019).

\footnotetext{
${ }^{9}$ After the baby Tsepang rape case the visibility of child rape increased to the extent that it was labelled a national crisis, with no less than 58 child rape cases a day (Posel, 2005: 246). So unprotected did women feel that one woman designed and produced chastity belts for girl babies and younger girls. For women she produced a 'rape condom' that looked like a tampon, but was hollow inside. The inner wall of the tampon is lined with small hooks. When the perpetrator inserts a penis into a vagina of someone wearing a rape condom, the inner sheath, which is armed and wired, attaches itself to the penis through the small hooks. The condom could only be removed by a doctor (Nuttall, 2004). A subsequent discussion in the media feared that by using this contraption more women would get killed.

${ }^{10}$ See Artz and Smythe (2007) for an analysis of rape case attrition.

${ }^{11}$ In South Africa the gender neutral terms 'Ombud' is used instead of Ombudsman.
} 
This article investigates sexual violence through the lens of biopolitics, using Agamben's notion of a state of exception and bare life. I will argue that there needs to be a closer look at the neglected sexual and gender dimensions of biopolitics in settler colonial societies, and specifically at the continuities of sexual violence in the settler colonial society of South Africa with present day sexual violence. I will argue that women in post-colonial South Africa are exposed to very high levels of sexual violence through their abandonment by the law and state agencies which are supposed to implement the law. I end by considering the possibilities of resistance against bare life.

\section{AGAMBEN'S STATE OF EXCEPTION AND BARE LIFE}

In Homo Sacer (1998) Agamben draws on the theories of Aristotle and Hannah Arendt to explain biological existence, or life in general (zoe) and specific political life (bios) - the difference between mere life and a life of political significance. Bare life that arises from a state of exception or a state of indistinction that is neither zoe or bios, but a life stripped of political significance that exposes those who reside there (the homines sacri) to spectacular violence. Bare life's relation to politics is dual - exclusion from the polis, but at the same time inclusion through exclusion where life is still recognised, but stripped of political significance, and secondly, unlimited exposure to violation that does not count as crime. (Agamben, 1998: 72). The homo sacer is the target of the sovereign's violence that exceeds the force of law, but it is also authorised by that law (Ziarek, 2008: 90). Politics in late modernity is about the establishment of a borderline that creates a space that is deprived of the protection of law (Lemke, 2005: 5). The exclusion that results in bare life is necessary in order to understand the good life because the polis requires an unacknowledged Other, the homo sacer, against which to measure the good life (Reddy, 2016: 37-38).

In Agamben's theory the inclusion of bare life within the polis emerges in modern democracies. It is the hidden incorporation of bare life into the political realm and the structure of citizenship (Ziarek, 2008: 91). For Agamben the main characteristic of modern biopolitics is the state of exception in which there is a generalised suspension of the law. Unlike Foucault's view that modern politics is biopolitics because of technologies of control that create governmentalities to regulate entire populations, in late modernity, for Agamben, the state of exception is the rule (Pratt, 2005: 1053). ${ }^{12}$ In this sense, Agamben is not concerned with regulation but rather with the suspension of the law.

The state of exception and the politics of death (thanatopolitics), or what Mbembe calls necropolitics was most visible in what Agamben (1998:166) calls 'the camp' in references to Nazi concentration camps. 'The camp' is the state of exception where the sovereign has the right to exercise death, where the rule of law is suspended, and becomes permanent spatial arrangements that exist continually outside of the normal state of law (Mbembe, 2003: 13). The sovereign has the power to also condemn people to death within life, or to a living death.

The sovereign (the state in modern politics) has the power to condemn to bare life certain categories of people through their exclusion from the protection of the law (Pratt, 2005: 1054). This makes it difficult to see whether these people are inside or outside the juridical order. The blurring of biological and political life created conditions of modern biopower (Pratt, 2005: 1056; Ziarek, 2008: 91). Because the contradiction of inclusion/exclusion is at the heart of democracy in late modernity we live in close contact with categories of excluded people who have been abandoned by the law, such as refugees, asylum seekers, the homeless and destitute.

Ziarek (2008: 93) argues that Agamben refrains from explorations of rape as sexual political violence because it would complicate his concept of bare life that is always defined in relation to death and not sexual violation. For Ziarek bare life is implicated in gendered, sexist, colonial and racist configurations of the political (Ziarek, 2008: 89). Pratt (2005), as well as Sanchez (2004), Smith (2010) and Savarese (2010) engage the genderblind nature of Agamben's theory. One of the main criticisms is that he develops the notion of legal abandonment by equating it with political and biological life, or the public sphere of the city and the private sphere of the home (Pratt, 2005: 1055). Feminist theorising of the public/private divide shows how issues that are depoliticised are relegated to the private sphere and that the politics of inclusion and exclusion work very differently across genders. What type of political significance women can access relates back to how they can enter the political sphere from the private sphere. Therefore, the political distribution of power across gendered beings takes the form of the public/private divide, thereby hiding how women's lives, as well as sexual activities, are depoliticised, privatised and political life is masculinised. Viewed in this way, the public/private divide in modern democracies may be one of the most central instruments for excluding from political significance and abandoning from legal protection everyone designated feminine and thus private.

\footnotetext{
12 Agamben has been critiqued for collapsing zoe and bios into the same zone of indistinction. Lemke (2005) argues that for Agamben bare life is a catastrophic endpoint where he collapses the exception into the rule, while Foucault attempted to show how biopolitics through the regulation of bodies normalised an intimate relationship between life and death.
} 
By applying Agamben's notion of 'the camp' and 'bare life' to sexual violence on campuses in the USA, Collins and Dunn (2018) show how women students are excluded from the protection of law when it comes to sexual harassment and rape. They emphasise how the law reinforces the patriarchal structure that regulates the ordering of relationships between men and women. This situation becomes compounded when gender identities and behaviour do not conform to state sanctioned institutionalised hetero-patriarchal gender norms that are embedded in law (Collins and Dunn, 2018: 374; Smart, 1989). Their application to the Brock Turner ${ }^{13}$ college rape shows how the law abandons women students, through the very lenient sentence Turner got for raping an unconscious woman student, leaving her partly dressed and unconscious in an ally next to a dumpster. Pratt (2005) and Collins and Dunn (2018: 376) confirm through their research that there is a relationship between the relegation to bare life and the way gender relationships, under patriarchy, are constructed to prioritise race and heterosexuality that most often benefit white men. (Turner is distinguished as a white heterosexual male).

I now turn to applying the state of exception and bare life to settler colonial states where race, gender and sexuality are at the centre of the biopolitics that creates conditions for the abandonment by law.

\section{THE SETTLER-COLONIAL DIMENSION OF BIOPOLITICS}

Apart from their gender blindness, neither Agamben nor Foucault theorised the biopolitics of colonialism, specifically settler colonialism (Puar, 2017). By merely viewing settler colonialism - the type of colonialism that displaces or eliminates Indigenous populations by establishing settlers as the new rulers - as a variant of colonialism we miss the important difference that in settler colonialism biopower is the product and process of colonial work (Morgensen, 2011: 55). It is the origin of measures to control and regulate populations through condemning some to bare life in a state of exception that became a condition of biopower in modern societies. This explains the continuation of colonialism even after its assumed demise (Morgensen, 2011: 59). What characterises settler colonialism is the 'logic of elimination' (Patrick Wolfe's concept, in Morgensen, 2011) through deadly violence. Indigenous populations had to fight extermination in forms of genocide and its coupling with displacement. Biopower, therefore, originated in settler colonies rather than being the externalisation of racialisation from Europe, normally viewed as the exception.

Settler colonial societies were faced with a conundrum of how to govern Indigenous people that survived elimination. In order to rule Indigenous populations through distinctive modes of governing settler colonists incorporated these populations into the body politic of the settler nation state. In South Africa, settler colonial relations produced an interdependency between settlers and Indigenous peoples, through patriarchal alliances with traditional leaders. This type of inclusion made Indigenous peoples into subjects living under customary law, rather than citizens, exposing them to the whims of traditional leaders who were and still are deeply patriarchal (see Mamdani, 1996).

Processes of colonisation and settlement are also deeply gendered. Morgensen by (2012: 2-7), drawing on Ann Stoler's work shows that race, gender and national power arose in colonial states. The gender/sexuality nexus is intrinsic to processes of colonisation of Indigenous peoples. Western constructions of gender and sexuality become naturalised so that the perception is formed that there is a natural sex and gender order underneath the violence that colonialism produces. What post-colonial feminists have shown is that:

... heteropatriarchal colonialism has sexualised indigenous lands and peoples as violable, subjugated Indigenous kin ties as perverse, attacked familial ties and traditional gender roles, and all to transform indigenous peoples for assimilation within or excision from the political and economic structures of white settler societies (Morgensen, 2012: 4).

Gender and sexuality, just as race, were produced and mobilised in what Stoler (2010) calls 'the intimacies of empire' through the regulation of women's sexuality, their reproduction, marriage and genealogy. The power of regulation was institutionalised and embodied through sexual violence. Settler colonialism introduced Western heteropatriarchy and the binary sex/gender system on foreign lands, indigenising the logics of Western sexuality as universal (Morgensen, 2012: 13). It forced Indigenous peoples to conform this logic of sexuality and eliminated their own histories and relations of sexuality (see for example Oyeronke, 1996).

The South African settler colonial state embodied both the violent logic of elimination and displacement as well as including Indigenous peoples into the settler nation through Western law. As Reddy (2017: 88) argues that from the first days of colonial conquest violence was meted out to local communities, thus confirming that they

13 Sam Levin, 'Brock Turner Laughed after Bystanders Stopped the Stanford Sexual Assault, Files Show' [https://www.theguardian.com/society/2016/aug/26/brock-turner-stanford-sexual-assault-victim-testimony-

laugh\#: : :text=The $\% 2020 \% 2$ Dyear\%2Dold\%20was,dumpster $\% 20$ on $\% 2018 \% 20 J a n u a r y \% 202015]$. (Accessed 24 January 2021).

$4 / 12$

(C) 2021 by Author/s 
are the homines sacri who do not have any political significance, other than to be on the receiving end of attempts to civilise and modernise them. In the process their communities were destroyed through land dispossession and migrant labour, reducing them to bare life. Enveloped by racist attitudes and used as cheap labour by racial capitalism, they were incorporated into colonial relations of domination.

In the case of South Africa there is the dual burden of having been a site of slavery and a settler colonial society at the same time. The biopolitics of slavery, theorised by Mbembe (2003) and Weheliye (2014), as well as settler colonial racism and violence apply to South Africa. Gqola (2015: 40) in an analysis of slavery in the settler colonial state of South Africa argues that slave women's sexuality was treated and dishonoured through rape, their bodies being property of slave owners, preventing control over their own sexuality. Sexual control by slave masters was violent and rape was routine. This type of violence was part of the founding violence of the colony.

Slave societies gave birth to stereotypes about slave and Indigenous women - that they are hypersexual and impossible to satiate, constructing them as legally impossible to rape. Even when freed, slaves could be raped without repercussions. Through the treatment of slave women as objects of sexual violation rape became institutionalised (Gqola, 2015: 43). Male slaves were viewed as also having ravenous sexual appetites and therefore as a danger to white women, who could be raped. For settler colonised societies the biopolitics of control of Indigenous women's sexuality was of utmost importance to prevent miscegenation, varying from regulating their fertility to pathologising their sexuality or studying it, or displaying and dissecting their genitalia as in the case of Saartjie Baartman ${ }^{14}$, even though the rape of Indigenous women by white men was not controlled. Sexuality therefore became an important way in which the colonial Otherness was constructed (Gqola, 2015: 44). As Gqola (2015: 38) astutely remarks, 'race was made through rape in very direct, deliberate and indirect ways (...)'. Gqola's work shows that the biopolitics of race and gender in settler colonial societies bears a direct relationship to how women's sexuality was regulated through violence (see also Baderoon, 2015).

The colonial wounds of subjugation also carry the psychological injury of rape on the collective level because of its impact on the individual level. As Du Toit (2009: 79) argues rape destroys one's sense of self in relation to one's world, it also destroys one's sense of one's relations with others in relation to one's world (what she calls 'loss of voice') and in relation to oneself (what she calls 'loss of rage'). It can be considered a living death or the work of necropolitics, because of Indigenous and slave women's powerlessness to eradicate the consequences of their sexual violation.

Below I will illustrate how settler colonial continuities of sexual violence create bare life for women in present day South Africa through the abandonment by law through the state agencies (police and the criminal justice system) that are supposed to implement the law. I will use the rape trial of the former President of South Africa, Jacob Zuma and lesbian rape and killings as illustrations.

\section{SEXUAL VIOLENCE AND ABANDONMENT BY LAW IN POST-COLONIAL SOUTH AFRICA}

The statistics provided at the beginning of this article to sketch the context of gender- based violence in South Africa is an indication of the prevalence and normalisation of sexual violence. Drawing on the work of Pratt (2005) I will show that a state of exception is created for women as they are abandoned by the same laws that include them in the body politic. For Agamben abandonment is not the same as exclusion. It is an active, relational process where those who are abandoned remains in a relationship with sovereign power (the state). This relationship means inclusion through exclusion (Pratt, 2005: 1054).

This contradiction of being included but also excluded is maintained through the regulation and maintenance of individual bodies. These are the ones who are considered impure, ageing, foreign, disorderly and contagious the ones who are costly to society, or the ones who are deemed irresponsible in regulating their own lives and health and discipline their bodies as neo-liberal citizenship requires through notions of self-care. These categories of people are deeply raced and gendered. Moreover, geographies form part of how certain people or categories of people are reduced to bare life (Pratt, 2005: 1055). Certain geographies are more exposed to violence where it becomes normalised in these places (e.g. places where sex work takes place - see Sanchez, 2004 and Savarese, 2010), or where people live, for example in informal settlements near waste dumps and industrial sites, associating them with squalor, illness and death. People's lives in these spaces are often led into borderlands where the illegitimate status of citizenship determines their movement and the social and economic value of their lives. What needs to be considered before we even consider the patriarchal nature of law is its 'absent presence' because of the high rates of lawlessness in South Africa, where the rule of law means little or law is flouted. When the law is not

\footnotetext{
${ }^{14}$ Saartjie Baartman was a Khoi woman who was enslaved and taken to Europe in the early 1800 s to be put on public display so that viewers could look at her genitalia [https://www.sahistory.org.za/people/sara-saartjie-baartman] (accessed 5 October 2020).
}

(C) 2021 by Author/s 
enforced people will draw on cultural constructions of sexuality to justify their behaviour. In post-(settler)colonial South Africa the colonial construction of culture is often drawn on to justify violence in the form of a cultural defence (see Gouws, 2014). The rape trial of Jacob Zuma is a good example of this, when he claimed that there was a cultural obligation on him to satisfy an aroused women.

\section{THE ZUMA RAPE TRIAL}

The era under Jacob Zuma's presidency showed the continuities with settler colonial impositions of narrative frames of African culture and tradition that were produced as pacts between colonial governors and traditional leaders. As Robins (2008: 422) points out the performance of African masculinity by Zuma (during his rape trial) was not that different from the ideas about Zuluness and customary law produced by the British colonial governor Shepstone (1877-1893).

While many theories attempt to explain the high levels of sexual violence in contemporary South Africa (see Du Toit, 2014; Buiten and Naidoo, 2016) there is a link between settler colonialism and the construction of masculinity during the colonial period, apartheid and post-apartheid that is now framed as a crisis in masculinity as a consequence of sexual violence. Ratele (2014: 137) points out how historically inferiorised traditions (often a consequence of colonial power's codification of indigenous oral traditions into law) are incorporated into the postapartheid foundational law framework, opening up claims for recognition by new political powers. Even colonial and apartheid language was incorporated, such as the use of the word 'tribe' (Ratele, 2014: 136). This recognition ultimately determines what is to be regarded as tradition. Through an array of laws (for example the Communal Land Rights Act and the (rejected) Traditional Courts Bill) that retribalise post-apartheid communities, law makers managed to, as Ratele (2014: 138-139) puts it:

[U]nwittingly affirm what might be called racialised, tribalistic masculinity and (hetero) sexism among blacks in rural areas. In retribalizing black life, all men are made out to be (...) rampant, warrior-like heterosexuals, and all African women as willing, submissive sexual objects of the men of the tribe.

There is a relationship between the colonial construction of tradition/culture and violent masculinities, through which violence and war talk are celebrated (Gqola, 2015: 152). Gqola argues that constructions of manhood postapartheid are for many the claim for adult agency in the face of colonial and Apartheid infantilisation (adult men being called boys and women girls) and emasculation. As she states:

While this emasculation discourse challenges the infantilization that Black men suffer in racist white regimes, this claim to recover from emasculation very often requires the performance of hypermasculinity that women are expected to support as part of enabling these men to attain manhood (Gqola, 2015: 156-157).

But, as Baaz and Stern (2013) in their studies of rape in war in the Democratic Republic of the Congo point out, sexual violence through the enactment or performance of hypermasculinity cannot produce masculinity. Every rape becomes an act to prove masculinity, yet in order to prove it, rape needs to be continuously re-enacted. As they surmise (Baaz and Stern, 2013: 28) '[R]ape serves as a performative act that functions to reconstitute [men's] masculinity - yet simultaneously symbolises their ultimate inability to do so.' Hence, rape continues unabatedly.

The rape trial of Jacob Zuma in 2005/2006 who was South Africa's president from 2007 to 2017 is a good illustration of the continuities of colonial violence and cultural constructions of masculinity and the complicity of sovereign power in sexual violence. Zuma was the vice-president of South Africa at the time of the trial. The outcome of this case strengthened the impression that men are entitled to rape with impunity. The Zuma rape trial inflicted the worst kind of secondary victimisation possible on a rape survivor. She was stoned on her way to court. People (many who were women) outside the court sang 'burn the bitch' while burning her photograph. Inside the court she was stigmatised as a 'serial rape accuser' who did not understand the difference between consent and non-consent. Her evidence was not viewed as reliable after her sexual history was introduced (in similar vein as Smart (1989) has argued about rape trials that disqualify women's experiences). Neither Zuma nor the male judge acted to stop the victim's or feminist supporters' victimisation. Zuma was acquitted for a 'lack' of evidence and went on to become the President of South Africa. The complainant had to flee the country for her own safety, and for all intents and purposes lost her citizenship, to be reduced to bare life in another country (see Hassim, 2009; Thabi, 2017). When you leave a country in self-imposed exile you leave behind the rights and privileges of citizenship, such as the protection of the law. In a country where you are not a citizen or do not have permanent residence you may not have the protection of the law, access to health and psychological care, or access to a job and housing. The probability is high that someone in conditions like that may end up destitute. Zuma, on the other hand, flaunted his sexual exploits in the public sphere with virtually no repercussions for his political career; on 
the contrary it gained him political support. The trial allowed him to flaunt his sexual potency, but also his potency as a political leader. What this trial also did was to emphasise Moffett's (2006) point that rape is rewritten as a story of race (and culture), not of gender - the story of a powerful black man who was 'framed' for rape.

The gendered organisation of power held by traditional leaders is pervasive and the rigid legal rules that were constructed led to the control of land, cattle, women and children through the reinforcement of patriarchal rules (Gouws, 2014: 42). Zuma exploited these constructions of culture and tradition during his rape trial. He firstly constructed himself as a Zulu warrior. As Suttner (2009: 231) points out the warrior tradition entails heroic acts and the condoning of rape and abuse of women, very often ending in forced marriage. (Zuma offered to pay the bride price for his victim so that she could become his wife.) Forced marriage to a woman from another tribe was considered a victory in war. The warrior tradition allows for noble deeds, but also for the abuse of women. The leadership of Zuma presented violent masculinities, engaging war talk and threats. He arrived, for example, at the court singing a struggle song 'Bring Me My Machine Gun' ('Umshini Wam'). As Suttner (2009: 229) puts it '[S]inging about machine guns was itself at one level a manifestation of male power over women, a symbolic representation of the power of the gun - a phallic symbol'. The song re-enacted rape because the word umshini is widely used as a euphemism for the penis in some African communities.

The white judge entered into a patriarchal pact with Zuma during which he (the judge) bought into the cultural stereotypes of what a raped woman should do and how she should act, and notions of male desire. He reprimanded Zuma like a father would, calling him 'my son'. Zuma addressed him as ' $n k o s i$ - yenkantolo' - king of the court. The protection of extended family as part of African tradition drawn on by the victim, who viewed Zuma as her uncle (malume), was ignored by the judge (Suttner, 2009: 229). As Robins (2008: 423) points out the tradition/modern binary used was politically highly productive because it created conditions in which the cultural defence used by Zuma went unchallenged. For example, Zuma said that not satisfying an aroused woman would be akin to rape in his culture. He talked about her vagina as 'her father's kraal' (cattle pen), that he entered without a coat (condom), but according to Zuma the situation could be rectified if he paid lobola (the bride price) to the victim and then she could become his wife, reinforcing notion of sexual entitlement in which women have no say. Zuma was applauded by Zulu traditional leaders (chiefs) wearing only loin cloths, sitting in the front row of the court. Why this strategy was so effective, according to Robins (2008: 422), is that in post-colonial societies reified notions of African culture carry considerable clout in courts and on the streets ${ }^{15}$. The mutual patriarchal understanding between Zuma and Judge van der Merwe 'revealed how lingering colonial legacies of racial paternalism continued to discursively link sex, gender and race in post-apartheid South Africa' (Robins, 2008: 416).

Zuma used the colonial understandings of warrior masculinity of bravery and conquest to justify nonconsensual sex, while the white judge affirmed this understanding of Zulu culture, rather than drawing on a human rights culture and a constitution that is supposed to protect women from violence. Zuma supporters, both men and women, performed violent masculinities outside the court through the violence inflicted on the victim, while wearing T-shirts emblazoned with words like ' $100 \%$ Zulu boy' (Zuma) or 'Zuma rape me!'. How the law abandoned the victim is clear in the way it trivialised and disqualified the victim's experiences on the individual level, but on a collective level it indicated to women that reporting rape or going through a rape trial is the worst possible thing to do.

\section{LESBIAN KILLINGS}

The violent processes of colonialism that impose heterosexuality are still employed in current postcolonial contexts to stabilise racialised and gendered hierarchies (Muholi, 2004: 123). As Judge (2018: 51) remarks '[T] he violent ordering of sexualities, integral to colonial and apartheid ideologies, produce a set of historical conditions in which contemporary formations of homophobia-related violence are to be located'. This invalidates gender and sexual non-conformity up unto this day. It also explains why lesbian rape is disproportionately inflicted on black lesbian women. Drawing on Agamben's notion of bare life, Gunkel (2010: 60-61) refers to the work of Perinelli who uses the notion of 'exclusive inclusion' arguing that hegemonic masculinity discursively pushes nonconforming masculinities to the margins. In the settler colony of South Africa, white men were distinguished as the centre, and white women were included to reproduce the white nation in the centre, even though their position was constructed as belonging in the private sphere. White lesbian women could remove themselves from this female domesticity, but lost their position in the centre, leading them to become part of exclusive inclusion. Homosexuality (under apartheid) therefore was constructed as white and male, and black men and women and white lesbian women were pushed to the margins. The notion of being gay as (un)African (the idea that African people have never been homosexual, was also defended by Zuma) and only arose in post-apartheid South Africa

${ }_{15}$ Many South African men view Zuma as the epitome of successful masculinity that socially excluded men could emulate being the Head of State, with only a primary school education and having four wives when he became president.

(C) 2021 by Author/s 
in order to support notions of an 'authentic' African culture, as was so well illustrated with the Zuma rape trial (Gunkel, 2010: 70). This myth is often used to justify violence against lesbian women also called 'corrective or curative' rape.

Corrective rape is performed by men who believe that they can 'cure' lesbian women from nonconforming sexual identities. These are acts of violence also spill over onto other women who have to be taught a lesson, such as the daughters of lesbian women. The statistics for lesbian rape is very high in South Africa. In 2011 it was estimated at 500 per year and in a study done $86 \%$ of lesbian women in the Western Cape said they live in fear. Only a fraction of cases of lesbian rape is prosecuted. By 2011 there was only one conviction in 31 cases of lesbian rape and murder. Lesbian women in general do not report rape, because they fear that when their identities become known they will be further victimised, also by the police (Di Silvio, 2011). As Judge's (2018) very important study of the rape of black lesbians in South Africa has shown that even talking about 'lesbian rape' constitutes the rape of lesbians as a separate class of rape 'obscuring how all rapes are disciplining acts that fulfil a corrective function in service of heteropatriarchal policing of gender and sexuality' (Judge, 2018: 68). This heteropatriarchal policing retards responses to all rape, as Di Silvio's (2011) discussion of the Carmichele vs the Minister of Safety and Security rape case shows. The judgment in this case has clearly instructed the government on how to meet its obligations toward women to prevent sexual violence. While the judgement in this case was delivered in 2000 the government is still in breach of developing policies that would meet the requirements set out in the judgment.

This case for Di Silvio puts a positive duty in relation to constitutional rights on the government to protect women from all forms of violence and for political leaders to demonstrate real leadership to tackle corrective rape $^{16}$. As Di Silvio (2011: 1473) puts it: The real violence of corrective rape, then is that despite South Africa's legal success in protecting gay rights and its promise of a post-apartheid South Africa that values human rights, the government has not done enough to stop corrective rape'. Di Silvio (2011) shows that there is a legal precedent in the Carmichele case that puts an obligation on the state to do more to protect women from violence. This case revolutionised the common law and updated the duties government owes its citizens.

Alix Carmichele was brutally raped and nearly killed by an awaiting trial rapist who raped and attempted to murder a woman. He was released on his own recognisance, even though he was considered dangerous. Carmichele then sued the state for damages. The Supreme Court and the Court of Appeal ruled that there was no wrongful action by the state. The Constitutional Court, however, overturned the ruling on grounds that the Constitution protects 'dignity, equality and freedom' and that the police have a general duty to protect the most vulnerable in society (Di Silvio, 2011: 1483). The ruling was revolutionary because it allows the state to find remedies for corrective rape (Di Silvio, 2011: 1484). The ruling also sets a precedent that sexual violence is not a private matter, but that women are entitled to protection by public officials. It makes clear that the government must bear the burden of protecting women from corrective rape, but despite this remedy has failed dismally to do so. It also imposes duties on the police to protect women, by improve police training, standardising procedures for investigating a rape complaint, creating reporting systems for victims of anti-gay crimes and specialised womenled sexual assault units, awareness raising programmes and guidelines to address service provider discrimination, provide shelters and adequate housing, support initiatives for abused women and public education programmes (Di Silvio (2011: 1512).

Di Silvio (2011) points out the continuities with apartheid violence where there were continuous threats of rape for (black) women who were detained and the sexual abuse of women by security forces was common. One of the reasons was that the apartheid police force was used to protect white people from black people, not to protect black communities from crime (Di Silvio, 2011: 1476). The Group Areas Act (that prevented white people and black people from living in the same areas) relegated many black people to areas which were lawless, isolated and impoverished with no protection from the police. Here women were without legal protection and subjected to male oppression (Di Silvio, 2011: 1476). Police allowed violence in black townships to go unchecked. Regardless of sexual violence that created a state of exception for women the state remains in breach of its duties as set out in the Carmichele case.

What drew attention to the legacies of colonialism and sexual violence was student resistance that came to a head on all the campuses of South African tertiary institutions in 2015, called the \#campaigns to directly protest colonial legacies. These campaigns were inter alia an indictment of political transition that included black people into the liberal democratic project and Western law, without really changing conditions of unfreedom. As Gibson

\footnotetext{
${ }^{16}$ The author was a commissioner for the South African Commission for Gender Equality and during my term in office a complaint was made at the commission by the mother of a murdered lesbian daughter in Nyanga, a township close to Cape Town, alleging that the police refused to investigate her daughter's murder. In my investigation into this matter, I was obstructed by the station commissioner at Nyanga police station and the detectives on the case. The detective work was sloppy, there was a disinterest to follow up on leads and a general tardiness. Having had the power to call a public hearing, I did so. All kinds of promises were extracted from the police during the hearing. A year later when my term ended there was still no progress in the case.
}

$8 / 12$

(C) 2021 by Author/s 
(2011: 48) remarks: 'In the situation where the legacies of colonialism - economic, social, cultural and psychological - are bracketed off, we can find only the limited liberation of 'enfranchised slaves', or bare life.

\section{RESISTANCE AGAINST BARE LIFE}

Agamben's theory of the state of exception and bare life paints a bleak picture that may have us believe that escaping from exclusion and abandonment by law is impossible. Ziarek $(2008: 89 ; 2102)$ asks the question whether bare life can be mobilised by emancipatory movements. If we rely only on the understanding of bare life as a life stripped of political significance, as a form of life of unlimited exposure to violation that does not count as a crime, will we expect resistance? Where the politicisation of bare life, however, occurs as Reddy (2015) argues about extraordinary politics in South Africa, mobilisation of homines sacri is possible ${ }^{17}$. Baishya (2012: 140) calls this the agency that occurs in zones of darkness outside the limits of normalised regimes of law and order.

The \#campaigns started around black students' expressions of feeling excluded and alienated from white (what they called colonial) institutional cultures at universities, where they did not see their values and culture reflected. Their alienation was reinforced by numerous colonial symbols (such as the statue of Cecil John Rhodes on the campus of the University of Cape Town that started the \#RhodesMustFall campaign). Even though students were united around fighting colonial legacies women were not exempt from sexual violence by their male allies. In 2016 \#EndRapeCulture started to draw attention to how sexual harassment and rape create conditions through which women students are neglected by university managements and abandoned by the law.

In the \#EndRapeCulture campaign women students expressed the simultaneity of oppressions. As Mohanty (1991: 10) has remarked, that is something that is fundamental to the experience of social and political marginality and how the relationality/intersectionality of race, gender and sexuality is conditioned under colonial circumstances and extended to the present. It was simultaneously a rejection of colonial patriarchy as well as embracing intersectional feminism (race, gender, sexuality and class, etc.) to locate themselves in a matrix of domination (the way in which different identities expose women differently to sexual violence). At Rhodes University the 'RU Reference List' featured the names of 11 men accused of rape that the university did not want to act against until due process has taken its course, triggering country wide protests against rape culture on university campuses. It confirmed Collins and Dunn's (2018) argument that campuses are spaces of exception where women students experience bare life because of the abandonment (neglect) by the law.

Many women who participated in the \#EndRapeCulture campaigns did so topless, bearing their breasts. This action references long standing traditions of African women disrobing to show their anger and distress with social, economic or political conditions (see Gouws, 2017, 2018). Universities were exposed for being complicit in concealing sexual violence or for not acting against perpetrators. What \#EndRapeCulture critically engaged was the normalisation of rape culture (practices, perceptions and attitudes that normalise sexual violence) in South Africa, of which universities are microcosms. But more than that it showed the entanglement of race and gender in sexual violence in post-colonial societies. When black women students (many of them feminists) started calling out black male students for sexual violence the focus shifted to critique of black men. Hassim (2014: 218) makes the important point that a feminist critique of patriarchal power is perceived as complicity in the reproduction of the 'colonial collective subconscious', because it is perceived as opening up the black male body to the white gaze.

What \#EndRapeCulture showed was that even though sexual violence may create bare life for women they do not passively have to accept it. In the state of exception produced through sexual violence in South Africa it was the new understandings of colonial framings among African women students that created a resignification of the body through its undressing in the context of violence reducing them to bare life. Naked protests can be the expression of the status of speechless bare life - an unconditional acceptance of that designation (as in the case of the Meitei women in Manipur who stood silent and naked in front of an army barracks of soldiers who raped and killed a woman) (Tyler, 2013: 215). This resonates with Weheliye's (2014) notion of racialisation in conditions of bare life reducing black people to mere flesh (the babeas viscus) through violence and dehumanisation.

Or women bearing their breasts can also be viewed as a refusal to be treated as mere flesh for men to rape (Tyler, 2013: 215). It engenders a certain defiance of the sovereign's inaction that reduces them to bare life. It also introduces the corporeal into the political space that challenges the notion of abandoned bodies in bare life that can be used and dispossessed through the neglect of the sovereign (Baishya, 2012: 139). Naminata (2019: 6) who specifically investigates women's disrobing as an African tradition argues that looking through a lens of biopolitics makes sense in an era that is characterised by what is considered the futility of agency and resistance against tyrannical regimes of power. For her agency needs to be interpreted in relation to constraint. She argues that her concept of naked agency (disrobing) expands Agamben's 'naked life' (she prefers this term instead of bare life). As she states:

${ }^{17}$ For an interpretation of constant protest by the poor and socially excluded in South Africa see Brown (2015).

(C) 2021 by Author/s 
The openness and the nakedness of positions of emancipation and constraint reflect more accurately the unstable political subjectivity that has developed within current sociopolitical arrangements, in which the state of exception (...) and the widespread sense of perishability are now normalized (Naminata, 2019: 6).

In the case of naked agency, both a sense of desperation and power are operative. Naked protests can be confrontational, defiant, shame-inducing or acts of powerlessness, but whatever they signify they show that women, even in a state of exception, is not without agency or mere passive victims of the state's abandonment or neglect.

Protest against sexual violence in South Africa has escalated beyond university campuses. In 2017 \#TotalShutDown mobilised women across the country to bring the country to a standstill so that the state had to take note of its own inaction against sexual violence. In 2019 more than 5,000 people protested in front of parliament and many more across the country to express their outrage about Uyinene Mrwetyana's death. They protested until the President came out of parliament to address them, also promising a National Strategic Plan on Gender Based Violence, a National Council on Gender Based Violence and funding for interventions. While the state of exception makes every woman in South Africa a potential target of sexual violence it does not necessarily reduce them to voicelessness on a collective level ${ }^{18}$.

\section{CONCLUSION}

In this article I have applied Agamben's theory of the state of exception and bare life to the very high incidence of sexual violence in South Africa. I have argued that present day sexual violence can be traced back to the founding violence of settler colonialism that constructed women's sexuality and men's masculinity in conditions of violence. Women's sexuality in settler colonies was regulated through biopolitics that rendered them into the state of exception and bare life through rape and a lack of control over their own sexuality. In the post-colonial democratic state women were included into the body politic, but still live in a state of exception because the sovereign neglects the implementation of the laws that included them and through which they should be protected from violence, thus bringing about the law's abandonment. Through very high levels of rape and intimate femicide women are exposed to the necropolitics of bare life, or state of exception that renders them outside the juridical order.

I, however, also argue that women have shown that it is not impossible to resist bare life through the \#EndRapeCulture Campaign and \#TotalShutDown in South Africa that demand accountability from the sovereign state to implement its own laws and provide women protection from violence. Bare life in relation to sexual violence is therefore not a totalising condition without hope.

\section{ACKNOWLEDGEMENTS}

The research for this article was made possible by NRF funding for the SARChI Chair in Gender Politics (Grant SARC98335).

\section{REFERENCES}

Abrahams, N., Jewkes, R., Laubsher, R. and Hoffman, M. (2006). Intimate Partner Violence: Prevalence and Risk Factors for Men in Cape Town, South Africa. Violence and Victims, 21(2), 247-264. https://doi.org/10.1891/vivi.21.2.247

Agamben, G. (1998). Homo Sacer: Sovereign power and bare life. Stanford: Stanford University Press. https:// doi.org/10.1515/9780804764025

Artz, L. and Smythe, D. (2007). Losing Ground? Making Sense of Attrition in Rape Cases, SA. Crime Quarterly, 22, 13-20.

Avert Report. (2020). Available at https://www.avert.org/professionals/hiv-around-world/sub-saharanafrica/soutafrica\# (Accessed 12 June 2020).

Baaz, M. E. and Stern M. (2013). Sexual Violence as a Weapon of War? London: Zed Press. https:/ / doi.org/10.5040/ 9781350222557

\footnotetext{
${ }^{18}$ Reddy (2016: 38) applying Agamben's theory of the homo sacer to South Africa, argues that the lives of the majority of South Africans are precarious without political significance. These conditions lead to what he calls extraordinary politics of daily protests, conflict and violence through which the homo sacer demands political significance (Reddy, 2016: 70). South Africans therefore show that it is possible to resist bare life.
}

$10 / 12$

(C) 2021 by Author/s 
Baderoon, G. (2015). Regarding Muslims: From slavery to post-apartheid. Johannesburg: Wits University Press. https://doi.org/10.18772/2014067694

Baishya, A. R. (2012). 'Counter Me, Rape Us': Bare Life and the Mimicry of the Sovereign, in A. De, A. Ghosh and U. Jana (eds), Subaltern Vision, (pp. 134-152). Newcastle: Cambridge Scholars Press.

Brown, J. (2015). South Africa's Insurgent Citizens. Pretoria: Jacana. https://doi.org/10.5040/9781350222700

Buiten, D. and Naidoo K. (2016). Framing the Problem of Rape in South Africa: Gender, Race, Class and State Histories. Current Sociology Monograph, 64(4), 535-550. https://doi.org/10.1177/0011392116638844

Cloete, N. (2019). Cops Warned Not to Turn Away Rape Victims at Police Stations. Available at https:/ /www.iol.co.za/weekend-argus/news/cops-warned-not-to-turn-away-victims-of-rape-at-policestations-35348119. (Accessed 13 June 2020).

Collins, E. V. and Dunn, M. (2018). The Invisible/Visible Claims to Justice: Sexual Violence and the University Camp(us). Contemporary Justice Review, 21(4), 371-395. https:/ / doi.org/10.1080/10282580.2018.1531717

Davis, H. and Todd, Z. (2017). On the Importance of a Dare, or Decolonizing the Anthropocene. ACME: An International Journal of Critical Geographies, 16(4), 761-780.

Department of Police (2019). Crime Stats 2019/2020. Available at https://www.saps.gov.za/services/ crimestats.php. (Accessed 28 March 2020).

Di Silvio, L. (2011). Correcting Corrective Rape: Carmichele and Developing South Africa's Affirmative Obligation to Prevent Violence against Women. Georgetown Law Journal, 99(5), 1469-1516.

Du Toit, L. (2009). A Philosophical Investigation of Rape. New York: Routledge. https://doi.org/10.4324/ 9780203397855

Du Toit, L. (2014). Shifting Meaning of Postconflict Sexual Violence in South Africa. Signs, Autumn, 101-123. https://doi.org/10.1086/676895

Gibson, N. (2011). Fanonian Practices in South Africa. Scottsville: UKZN Press.

Gouws, A. (2014). Multiculturalism in South Africa: Dislodging the Binary between Universal Human Rights and Culture/Tradition, in A. Gouws and D. Stasiulis (eds), Gender and Multiculturalism: North/South Perspectives (pp 35-55). London: Routledge. https://doi.org/10.1080/02589346.2013.765674

Gouws, A. (2017). Feminist Intersectionality and the Matrix of Domination in South Africa. Agenda, 31(1), 19-27. https://doi.org/10.1080/10130950.2017.1338871

Gouws, A. (2018). \#EndRapeCulture in South Africa: Resisting Sexual Violence Through Protest and the Politics of Experience. Politikon, 45(1), 3-15. https://doi.org/10.1080/02589346.2018.1418201

Gqola, P. (2015). Rape: A South African nightmare. Johannesburg: MF Books.

Gunkel, H. (2010). The Cultural Politics of Female Sexuality in South Africa. New York: Routledge. https://doi.org/10.4324/9780203856031

Hassim, S. (2009). Democracy's Shadows: Sexual Rights and Gender Politics in the Rape Trial of Jacob Zuma. African Studies, 68(1), 55-77. https://doi.org/10.1080/00020180902827431

Hassim, S. (2014). Violent Modernity: Gender, Race and Bodies in Contemporary South Africa, in A. Gouws and D. Stasiulis (eds), Gender and Multiculturalism: North/South perspectives (pp. 211-226). New York: Routledge.

Head, T. (2019). Femicide Rates: South Africa Versus the Rest of the World. Available at https://www .thesouthafrican.com/news/how-many-women-killed-south-africa-femicide/. (Accessed 2 October 2020).

Judge, M. (2018). Blackwashing Homophobia. New York: Routledge. https://doi.org/10.4324/9781315735368

Lemke, T. (2005). 'A Zone of Indistinction' - A Critique of Giorgio Agamben's Concept of Biopolitics. Outlines 1, 3-13.

Mamdani, M. (1996). Citizen and Subject: Contemporary Africa and the legacy of late colonialism. Princeton: Princeton University Press.

Mbembe, A. (2003). Necropolitics. Public Culture, 15(1), 11-40. https:/ / doi.org/10.1215/08992363-15-1-11

Moffett, H. (2006). 'These Women Force us to Rape Them': Rape as narrative of social control in post-apartheid South Africa. Journal of Southern African Studies, 32(1), 129-144. https://doi.org/10.1080/03057070500493845

Mohanty, C. (1991). Introduction, in C. Mohanty, A. Russo and L. Torres (eds), Third World Women and the Politics of Feminism (pp. 1-47). Bloomington: Indiana University Press.

Morgensen, S. L. (2011). The Biopolitics of Settler Colonialism: Right Here, Right Now. Settler Colonial Studies, 1(1), 52-76. https://doi.org/10.1080/2201473X.2011.10648801

Morgensen, S. L. (2012). Theorising Gender, Sexuality and Settler Colonialism: An Introduction. Settler Colonial Studies, 2(2), 2-22. https://doi.org/10.1080/2201473X.2012.10648839

Muholi, Z. (2004). Thinking through Lesbian Rape. Agenda, 61, 116-125.

Naminata, D. (2019). Naked Agency. Durham: Duke University Press.

Nuttall, S. (2004). Girl Bodies. Social Text, 78, 22(1), 17-33. https://doi.org/10.1215/01642472-22-1_78-17

Oyeronke, O. (1997). The Invention of Women: Making an African Sense of Western Gender Discourses. Minneapolis: University of Minnesota Press. 
Posel, D. (2005). The Scandal of Manhood: 'Baby Rape' and the Politicization of Sexual Violence in Post-Apartheid South Africa. Culture, Health \& Sexuality, 7(3), 239-252. https:/ / doi.org/10.1080/13691050412331293467

Pratt, G. (2005). Abandoned Women and Spaces of the Exception. The 2005 AAG Antipode Lecture. Editorial Board of Antipode, 1052-1078. https://doi.org/10.1111/j.0066-4812.2005.00556.x

Puar, J. (2017). The Right to Maim. Durham: Duke University Press. https://doi.org/10.1515/9780822372530

Ratele, K. (2014). Masculinities without Tradition, in A. Gouws and D. Stasiulis (eds), Gender and Multiculturalism: North/South perspectives (pp. 133-156). New York: Routledge.

Reddy, T. (2015). South Africa, Settler Colonialism and the Failures of Democracy. Johannesburg: Wits University Press. https://doi.org/10.5040/9781350222694

Report of the Independent Police Investigative Directorate. (2013). Available at https://ewn.co.za/2013/10/02/ IPID-probed-over-4000-cop-cases. (Accessed on 14 June 2020)

Robins, S. (2008). Sexual Politics and the Zuma Rape Trial. Journal of Southern African Studies, 34(2), 411-427. https://doi.org/10.1080/03057070802038066

Sanchez, L. E. (2004). The Global E-rotic Subject, the Ban, and the Prostitute-Free Zone: Sex Work and the Theory of Differential Exclusion. Environment and Planning D: Society and Space, 22(6), 861-883. https://doi.org/10.1068/d413

Sanday, P. R. (1996). Rape Prone versus Rape Free Campus Cultures. Violence Against Women, 2(2), $191-208$. https://doi.org/10.1177/1077801296002002006

Savarese, J. L. (2010). Doing No Violence to the Sentence Imposed: Racialized sex worker Complainants, Racialized Offenders, and the Feminization of the Homo Sacer in Two Sexual Assault Cases. Canadian Journal of Women and the Law, 22(2), 365-396. https:/ / doi.org/10.3138/ cjwl.22.2.365

Smart, C. (1989). Feminism and the Power of Law. London: Routledge.

Smith, A.M. (2010). Neo-Eugenics: A feminist critique of Agamben. Occasion: Interdisciplinary Studies in the Humanities 2. Available at http:// occasion.stanford.edu/node/59. (Accessed 15 June 2020).

StatsSA. (2000). Report on the Quantitative Findings on Rape in South Africa. Available at http:/ /www.statssa.gov.za/publications/Rape/Rape.pdf. (Accessed, 15 June 2020).

StatsSA. (2018). Crime against Women in South Africa Report, Available at https://www.statssa.gov.za/ publications/Report-03-40-05/Report-03-40-05June2018.pdf. (Accessed 14 June 2020).

Stoler, A. (2010). Carnal Knowledge and Imperial Power: Race and the intimate in colonial rule. Berkeley: University of California Press.

Suttner, R. (2009). The Jacob Zuma Rape Trial: Power and African National Congress (ANC) Masculinities. NORA Nordic Journal of Feminist and Gender Research. 17(3), 222-236. https://doi.org/10.1080/ 08038740903117174

Tlhabi, R. (2017). Khweqi. Johannesburg: Jonathan Ball.

Tyler, I. (2013). Naked Protests: The Material Politics of Citizenship and Revolt. Citizenship Studies, 17(2), $211-226$. https://doi.org/10.1080/13621025.2013.780742

Weheliye, A. G. (2014). Habeas Viscus. Durham: Duke University Press. https://doi.org/10.1515/9780822376491

Ziarek, E. (2008). Bare Life on Strike: Notes on the Biopolitics of Race and Gender. South Atlantic Quarterly, 107(1), 89-105. https://doi.org/10.1215/00382876-2007-057

Ziarek, E. (2012). Bare Life, in H. Sussman (ed), Impasses of the Post-Global: Theory in the era of climate change (vol. 2). Ann Arbor: Open Humanities Press. https://doi.org/2027/spo.10803281.0001.001

Citation: Gouws, A. (2021). Reducing Women to Bare Life: Sexual Violence in South Africa. Feminist Encounters: A Journal of Critical Studies in Culture and Politics, 5(1), 03. https://doi.org/10.20897/femenc/9740 